\title{
In vitro evaluation of mutagenicity and genotoxicity of sitagliptin alone and in combination with artificial sweeteners
}

\author{
Komal Najam ${ }^{1,2}$, Imran Altaf ${ }^{3}$, M Ashraf ${ }^{1}$, M Adil Rasheed ${ }^{1}$, Faiza Saleem ${ }^{4}$, \\ Neelma Munir ${ }^{4}$ and Rasheeda Bashir ${ }^{4 *}$ \\ ${ }_{1}^{1}$ Department of Pharmacology and Toxicology, ${ }^{2}$ Department of Pharmacy, Hajvery University Lahore, ${ }^{3}$ Quality Operation \\ Laboratory (QOL), University of Veterinary and Animal Sciences, ${ }^{4}$ Depertment of Biotechnology, Lahore College for Women \\ University, Lahore, Pakistan
}

*For correspondence: Email: rashidasbs@yahoo.com; Tel: +92 3074464628

Sent for review: 26 August 2016

Revised accepted: 11 July 2017

\begin{abstract}
Purpose: To determine the in vitro genotoxicity and mutagenicity of sitagliptin alone and in combination with three commonly used artificial sweeteners (saccharin, aspartame and acesulfame-k).

Methods: The in vitro genotoxicity and mutagenicity of Sitagliptin alone and in combination with three popular artificial sweeteners (saccharin, aspartame and acesulfame-k) were evaluated by Comet and Ames assays, respectively.

Results: Sitagliptin demonstrated mutagenic potential only to TA 98 with S9 mix at a concentration of $3040 \mu \mathrm{g} / \mathrm{plate}$. The mutagenicity of sitagliptin was enhanced when tested in combination with the artificial sweeteners. Furthermore, sitagliptin also caused pronounced DNA fragmentation at higher doses compared with negative control.

Conclusion: At higher doses, sitagliptin showed both mutagenicity and genotoxicity. Thus, long-term use of artificial sweeteners with sitagliptin may lead to increase in both mutagenicity and genotoxicity.
\end{abstract}

Keywords: Sitagliptin, Artificial sweeteners, Comet assay, DNA damage, Ames assay, Genotoxicity, Mutagenicity

Tropical Journal of Pharmaceutical Research is indexed by Science Citation Index (SciSearch), Scopus, International Pharmaceutical Abstract, Chemical Abstracts, Embase, Index Copernicus, EBSCO, African Index Medicus, JournalSeek, Journal Citation Reports/Science Edition, Directory of Open Access Journals (DOAJ), African Journal Online, Bioline International, Open-J-Gate and Pharmacy Abstracts

\section{INTRODUCTION}

Oral anti-diabetic drugs are the first line therapy for type 2 diabetes, sitagliptin recently is being used as oral anti-diabetic drug for type-2 diabetes management. Sitagliptin effectively helps to maintain blood glucose level in diabetic patients and also enhances the activity of beta cells when used in combination with metformin [1]. However, sitagliptin treatment is linked to increased pancreatic ductal turnover, ductal metaplasia, and pancreatitis [2]. Significant association is seen between diabetes, diabetes therapies, and cancer [3]. In fact metabolic dysfunction influences tumorigenesis because of which obese and diabetic patients are at greater risk of cancer [4].

Artificial sweeteners are more often used by obese individuals in effort to lose weight. However, psychological problems, mental dysfunction, bladder cancer, heart failure and brain tumors are some alarming side effects of the artificial sweeteners [5]. Saccharin was the principal artificial sweetener but its potential tumergencity declined its fame [6]. Saccharin is also considered to be responsible for weakness, 
low serum iron, vitamin $A$ and folate level as well as high serum vitamin $E$ and cholesterol level [7]. Aspartame is an artificial, non-saccharide sweetener and is considered to be closely linked with increased incidence of malignancy of brain tumors. It is suggested that long term use of aspartame might lead to improper antioxidant status of brain mainly through glutathionedependent system involvement [8].

Acesulfame $\mathrm{K}$ is a calorie-free sugar substitute, which is not metabolized by the body and is discharged unaltered. Although it is largely excreted from the urine, studies suggest that it can be excreted to the amniotic liquid and milk [9]. The main objective of the present project was to evaluate the mutagenic and genotoxic potential of saccharin, aspartame, acesulfame-k and sitagliptin alone and in combination. Moreover, these chemical were not only tested in their original chemistry but their metabolites were also tested in vitro by using mouse liver rate extract containing microsomal activation enzyme system (S9m

\section{EXPERIMENTAL}

\section{Materials and chemicals}

Artificial sweeteners like saccharin, aspartame and acesulfame-k were obtained from Harmann Pharmaceuticals Pvt Ltd, India, while sitagliptin was provided by the Highnoon laboratories Ltd to carry out this project. Metabolic activation enzyme system (S9) was obtained from Environmental Bio-detection Products Inc. (EBPI, Canada) in lyophilized form along with its co factors.

\section{Comet assay}

All procedures that involved animals were conducted in accordance with the National Institute of Health guide for the care and use of laboratory animals [10]. All experiment animals were approved by institutional review board (IRB) committee of Department of pharmacology and toxicology, University of Veterinary and Animal Sciences Lahore, Pakistan (ref no. 2011-VA537). Blood lymphocytes were used to evaluate the genotoxicity by comet assay. For this, blood lymphocytes of healthy sheep were obtained and separated by using lymphocytes separation media. Then the lymphocytes were exposed to various concentrations of the chemicals [11]. The exposed lymphocytes were mixed with $1 \%$ low melting point agarose and layered onto the base slides. After solidification, third layer of agarose 1 $\%$ was layered onto the same slide and allowed to solidify. Subsequently the slides were dipped in the lysing solution containing $2.5 \mathrm{M}$ sodium chloride, $0.1 \mathrm{M}$ ethylenediaminetetraacetic acid (EDTA), $10 \mathrm{mM}$ Tris, $1 \%$ Triton X-100 (pH 10) for $2 \mathrm{~h}$. The slides were then exposed to alkaline buffer consisting $1 \mathrm{mM}$ EDTA and $300 \mathrm{mM}$ sodium hydroxide $(\mathrm{pH}>13)$ for $20 \mathrm{~min}$. The cells were subjected to electrophoresis for $20 \mathrm{~min}$ at 25 volts and $300 \mathrm{~mA}$. Slides were visualized by using fluorescent microscope. Phosphate buffer saline was used as negative control and $20 \%$ DMSO was taken as positive control. DNA damage was evaluated by measuring the size of the comet of fragmented DNA. The results were recorded as described by the method designed by Valencia-Quintana et al [12].

\section{Ames assay}

Ames Salmonella/Microsome mutagenicity assay was performed with and without S9 metabolic system (+S9 and -S9 respectively) as illustrated by Mortelmans and Zeiger [13]. Two mutant strains of Salmonella typhimurium TA 100 and TA 98 obtained from environmental bio-detection products incorporation (EBPI) Canada for mutagenic testing of the drugs.

Briefly, $0.05 \mathrm{~mL}$ of overnight grown culture of strain of Salmonella, $0.1 \mathrm{~mL}$ of the agents to be tested (diluted with PBS), $0.5 \mathrm{~mL}$ of S9 (+S9) were mixed and incubated for $30 \mathrm{~min}$ at $37^{\circ} \mathrm{C}$. After incubation, the mixture was homogenized with $2 \mathrm{~mL}$ of top agar was poured onto a minimal glucose media in petri plate. The test was run in in. Plates were incubated at $37^{\circ} \mathrm{C}$ for $48 \mathrm{~h}$ and then revertant His+ bacteria colonies were scored. In each assays, a positive (sodium azide) and a negative (PBS) control were also run. The mutagenic index (MI) was calculated as the ratio between number of histidine revertant induced per plate of the test chemical and spontaneous revertant of the negative control. Mutagenic response was considered positive when numbers of colonies in test chemical plate were $\geq$ two fold than the natural revertant of negative control.

\section{Statistical analysis}

Statistical analysis was performed using SPSS software version 17, one-way ANOVA and Tukey statistical tests were used to compare the data. $P$ $<0.05$ was considered statistically significant.

\section{RESULTS}

The results show that increase in sitagliptin concentration resulted in a rise in its genotoxic potential. Maximum DNA damage was seen at the concentrations of $1520 \mu \mathrm{g} / \mathrm{mL}$ and 3040 
$\mu \mathrm{g} / \mathrm{mL}$ with damage index of 9 and 20 respectively (Figure 1).

Ames salmonella test when performed to evaluate the mutagenic capability of the sitagliptin (Table 1), it didn't demonstrate any significant mutagenic impact against TA100 and TA98 strains without the metabolic activation system. However significant mutation was seen in the presence of metabolic activation system against TA98 at the highest concentration of $3040 \mu \mathrm{g} /$ plate.

Saccharin (Figure 1) demonstrated genotoxicity in dose dependent manner. The tail length increased significantly with respect to the negative control. Saccharin at the doses of $20,000 \mu \mathrm{g} / \mathrm{mL}$ and $40,000 \mu \mathrm{g} / \mathrm{mL}$ exhibited the maximum damage index of 13 and 24 respectively. The results of Ames assay (Table 2) revealed that saccharin at concentration of 2500 and $5000 \mu \mathrm{g} /$ plate without S9 mix and at $2500 \mu \mathrm{g} /$ plate with $\mathrm{S9}$ exhibited significant mutagenic effects against TA 98 strain. Saccharin however at all concentrations between 2500 to $40,000 \mu \mathrm{g} /$ plate did not revealed significant mutagenic potential against TA100 with and without metabolic activation system.

Aspartame results illustrated dose dependent increase in the length of the comet tail indicating increase in the DNA damage with increase in the concentration relative to the negative control (Figure 2).

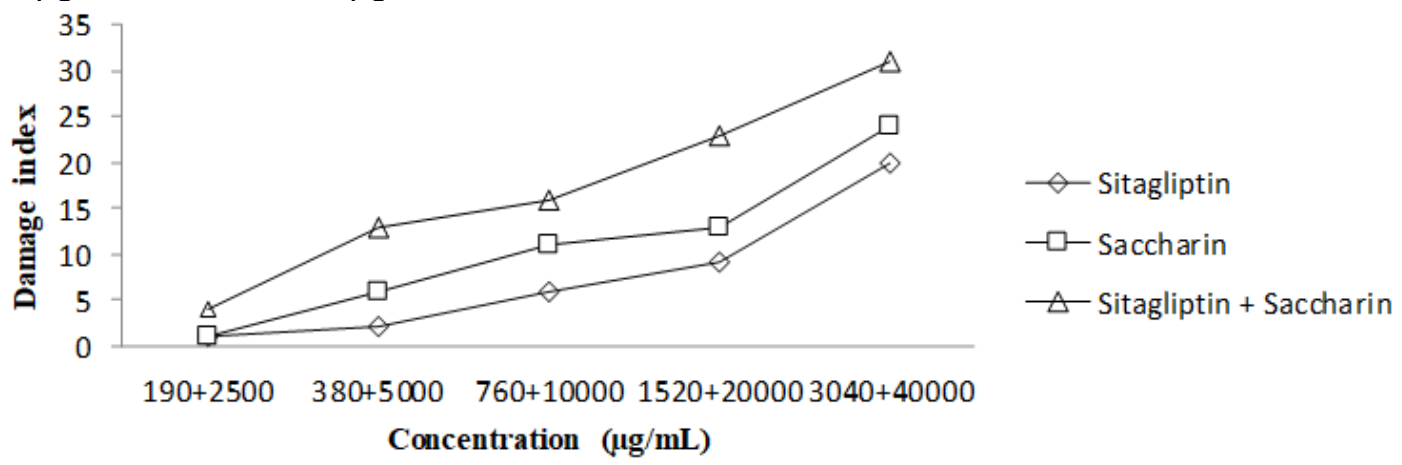

Figure 1: Damage index of sitagliptin, saccharin and sitagliptin + saccharin

Table 1: Mutagenic potential of sitagliptin

\begin{tabular}{|c|c|c|c|c|c|c|c|c|c|}
\hline \multirow[t]{3}{*}{ No. } & \multirow{3}{*}{$\begin{array}{c}\text { Conc. } \\
\text { ( } \mu \mathrm{g} / \text { plate) }\end{array}$} & \multicolumn{8}{|c|}{ Revertant colonies/plate } \\
\hline & & \multicolumn{4}{|c|}{ TA 100} & \multicolumn{4}{|c|}{ TA 98} \\
\hline & & +S9 & M.I. & -59 & M.I. & +59 & M.I. & -59 & M.I. \\
\hline 1 & 190 & 56 & 0.3 & 39 & 0.37 & 34 & 0.38 & 19 & 0.26 \\
\hline 2 & 380 & 68 & 0.36 & 40 & 0.38 & 42 & 0.47 & 22 & 0.3 \\
\hline 3 & 760 & 72 & 0.39 & 85 & 0.8 & 64 & 0.71 & 37 & 0.37 \\
\hline 4 & 1520 & 101 & 0.54 & 96 & 0.91 & 150 & 1.68 & 101 & 1.401 \\
\hline 5 & 3040 & 120 & 0.65 & 120 & 1.14 & 230 & 2.58 & 129 & 1.79 \\
\hline $\begin{array}{l}\text { Negative } \\
\text { control }\end{array}$ & 0 & 184 & & 105 & & 89 & & 72 & \\
\hline $\begin{array}{l}\text { Positive } \\
\text { control }\end{array}$ & 5 & 2096 & 11.39 & 758 & 7.21 & 563 & 6.325 & 360 & 5 \\
\hline
\end{tabular}

Table 2: Mutagenic potential of saccharin

\begin{tabular}{|c|c|c|c|c|c|c|c|c|c|}
\hline \multirow{4}{*}{ No. } & \multirow{4}{*}{$\begin{array}{c}\text { Conc. } \\
\text { ( } \mu \mathrm{g} / \text { plate) }\end{array}$} & \multicolumn{5}{|c|}{ Saccharin } & & & \\
\hline & & \multicolumn{8}{|c|}{ Revertant colonies/plate } \\
\hline & & \multicolumn{4}{|c|}{ TA 100} & \multicolumn{4}{|c|}{ TA 98} \\
\hline & & +S9 & M.I. & -59 & M.I. & $+S 9$ & M.I. & -59 & M.I. \\
\hline 1 & 2500 & 126 & 0.68 & 70 & 0.66 & 183 & 2.05 & 260 & 3.63 \\
\hline 2 & 5000 & 115 & 0.62 & 63 & 0.6 & 162 & 1.82 & 154 & 2.13 \\
\hline 3 & 10000 & 96 & 0.52 & 54 & 0.51 & 75 & 0.84 & 60 & 0.83 \\
\hline 4 & 20000 & 89 & 0.48 & 36 & 0.34 & 60 & 0.67 & 50 & 0.69 \\
\hline 5 & 40000 & 83 & 0.45 & 25 & 0.23 & 40 & 0.45 & 32 & 0.44 \\
\hline Negative control & 0 & 184 & & 105 & & 89 & & 72 & \\
\hline Positive control & 5 & 2096 & 11.39 & 758 & 7.21 & 563 & 6.33 & 360 & 5 \\
\hline
\end{tabular}




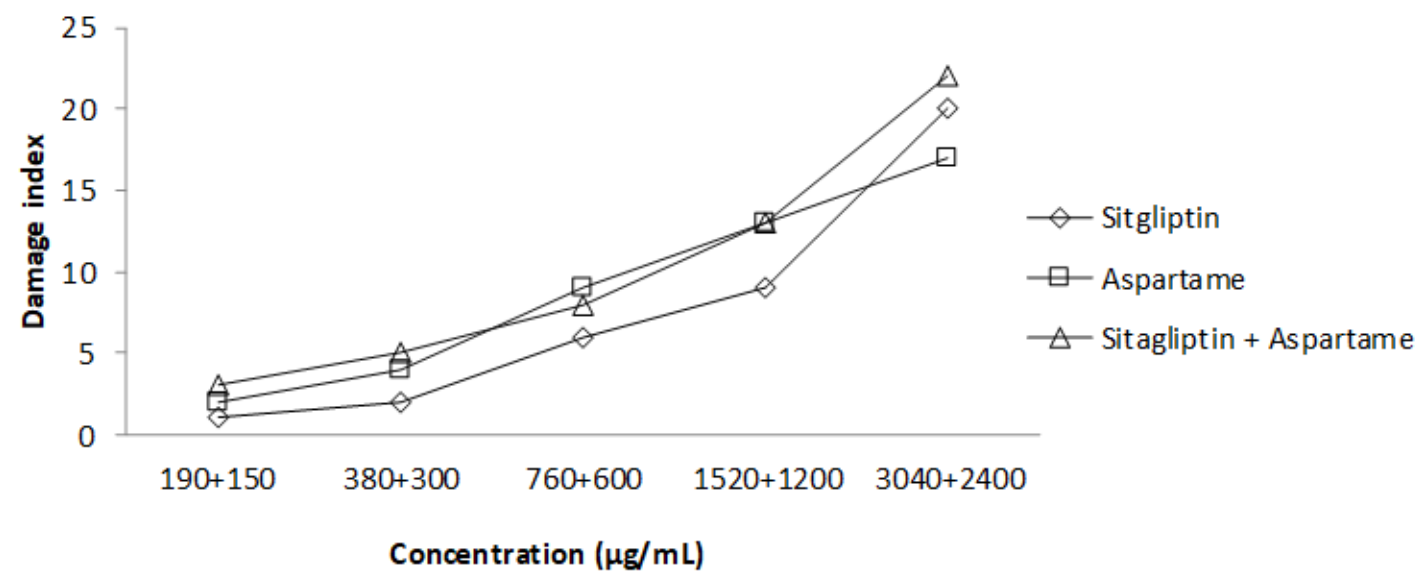

Figure 2: Damage index of sitagliptin, aspartame and sitagliptin + aspartame

Mutagenic evaluation of aspartame (Table 3) demonstrated significant mutagenic effects against TA100 at the concentration of 150 $\mu \mathrm{g} /$ plate and $300 \mu \mathrm{g} /$ plate in the presence of metabolic system.

Acesulfame-k exhibited significant dose dependent DNA damage to the lymphocytes as compared to the negative (Figure 3 ).
Acesulfame- $\mathrm{K}$ exhibited mutagenic effects at concentration of $800 \mu \mathrm{g} /$ plate and $1600 \mu \mathrm{g} /$ plate against TA98 strain in the absence of metabolic activation system (Table 4). No significant numbers of colonies were seen on GM agar plates with and without S9 mix when TA100 was used.

Table 3: Mutagenic potential of aspartame

\section{Aspartame}

\begin{tabular}{|c|c|c|c|c|c|c|c|c|c|}
\hline \multirow[t]{3}{*}{ No. } & \multirow{3}{*}{$\begin{array}{c}\text { Conc. } \\
\text { ( } \mu \mathrm{g} / \text { plate) }\end{array}$} & \multicolumn{8}{|c|}{ Revertant colonies/ plate } \\
\hline & & \multicolumn{4}{|c|}{ TA 100} & \multicolumn{4}{|c|}{ TA 98} \\
\hline & & $+\$ 9$ & M.I. & -59 & M.I. & $+S 9$ & M.I. & -59 & M.I. \\
\hline 1 & 150 & 369 & 2 & 86 & 0.81 & 54 & 0.6 & 42 & 0.58 \\
\hline 2 & 300 & 492 & 2.67 & 119 & 1.13 & 93 & 1.04 & 49 & 0.68 \\
\hline 3 & 600 & 210 & 1.14 & 80 & 0.76 & 83 & 0.93 & 57 & 0.79 \\
\hline 4 & 1200 & 192 & 1.04 & 62 & 0.59 & 79 & 0.88 & 34 & 0.47 \\
\hline 5 & 2400 & 176 & 0.95 & 60 & 0.57 & 75 & 0.84 & 21 & 0.29 \\
\hline Negative control & 0 & 184 & & 105 & & 89 & & 72 & \\
\hline Positive control & 5 & 2096 & 11.4 & 758 & 7.21 & 563 & 6.325 & 360 & 5 \\
\hline
\end{tabular}

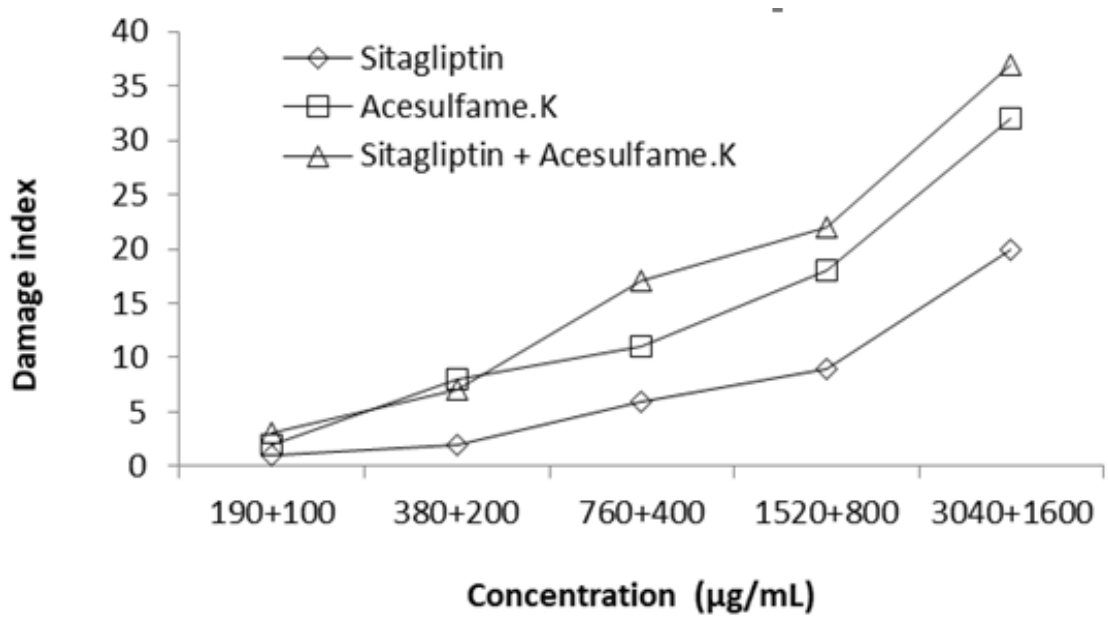

Figure 3: Damage index of sitagliptin, acesulfame-K and sitagliptin + acesulfame-K 
Table 4: Mutagenic potential of acesulfame-K

\begin{tabular}{|c|c|c|c|c|c|c|c|c|c|}
\hline \multicolumn{10}{|c|}{ Acesulfame-K } \\
\hline \multirow[t]{3}{*}{ No. } & \multirow{3}{*}{$\begin{array}{c}\text { Conc. } \\
\text { ( } \mu \mathrm{g} / \text { plate) }\end{array}$} & \multicolumn{8}{|c|}{ Revertant Colonies/plate } \\
\hline & & \multicolumn{4}{|c|}{ TA 100} & \multicolumn{4}{|c|}{ TA 98} \\
\hline & & +S9 & M.I. & -59 & M.I. & $+\$ 9$ & M.I. & -59 & M.I. \\
\hline$\overline{1}$ & 100 & 96 & 0.52 & 47 & 0.44 & "63 & 0.7 & 72 & 1 \\
\hline 2 & 200 & 123 & 0.66 & 52 & 0.49 & 79 & 0.88 & 102 & 1.41 \\
\hline 3 & 400 & 148 & 0.8 & 66 & 0.62 & 83 & 0.93 & 138 & 1.91 \\
\hline 4 & 800 & 154 & 0.83 & 87 & 0.82 & 129 & 1.44 & 220 & 3.05 \\
\hline 5 & 1600 & 169 & 0.91 & 95 & 0.9 & 133 & 1.49 & 231 & 3.2 \\
\hline Negative Control & 0 & 184 & & 105 & & 89 & & 72 & \\
\hline Positive Control & 5 & 2096 & 11.39 & 758 & 7.21 & 563 & 6.325 & 360 & 5 \\
\hline
\end{tabular}

In this project when the genotoxicity of sitagliptin was evaluated in combination with saccharin, the tail length increased in dose dependent fashion. Highest damage index of 31 was at the combination dose of $3040+40000 \mu \mathrm{g} / \mathrm{mL}$ (Figure 1). When different combinations of sitagliptin and saccharin was tested outcomes turned out to be mutagenic at three measurements of $380+5000$ $\mu \mathrm{g} /$ plate, $760+10000 \mu \mathrm{g} /$ plate and $1520+20000$ $\mu \mathrm{g} /$ plate to TA 98 both with and without S9 mixture (Table 5). The outcomes were noteworthy when sitagliptin and saccharin consolidated measurements were compared with sitagliptin dosages alone.
Similarly sitagliptin and aspartame when evaluated for genotoxicity (Fig 2), damage indices of $3,5,8,13$ and 22 represented dose dependent relationship with the concentrations. Results revealed no significant enhance in the genotoxicity of sitagliptin + aspartame as compared the genotoxic effects of sitagliptin alone. In case of sitagliptin + aspartame mutagenicity test (Table 6) results revealed that among all the combined doses of Sitagliptin and Aspartame, $760+600 \mu \mathrm{g} /$ plate and $1520+1200$ $\mu \mathrm{g} /$ plate were mutagenic only to TA98 with S9 mix. All of other combined doses were nonmutagenic against both TA100 and TA98 with and without metabolic system.

Table 5: Mutagenic potential of sitagliptin and saccharin in combination

\begin{tabular}{|c|c|c|c|c|c|c|c|c|c|}
\hline \multicolumn{10}{|c|}{ Sitagliptin + saccharin } \\
\hline \multirow[t]{3}{*}{ No. } & \multirow{3}{*}{$\begin{array}{c}\text { Conc. } \\
\text { ( } \mu \mathrm{g} / \text { plate) }\end{array}$} & \multicolumn{8}{|c|}{ Revertant colonies/plate } \\
\hline & & \multicolumn{4}{|c|}{ TA 100} & \multicolumn{4}{|c|}{ TA 98} \\
\hline & & + S9 & M.I. & -59 & M.I. & $+\mathbf{S 9}$ & M.I. & -59 & M.I. \\
\hline 1 & $190+2500$ & 152 & 0.82 & 156 & 1.48 & 144 & 1.61 & 90 & 1.25 \\
\hline 2 & $380+5000$ & 176 & 0.95 & 175 & 1.66 & 208 & 2.33 & 215 & 2.98 \\
\hline 3 & $760+10000$ & 195 & 1.05 & 195 & 1.85 & 212 & 2.38 & 252 & 3.5 \\
\hline 4 & $1520+20000$ & 152 & 0.82 & 199 & 1.89 & 360 & 4.04 & 266 & 3.69 \\
\hline 5 & $3040+40000$ & 145 & 0.78 & 146 & 1.39 & 153 & 1.71 & 139 & 1.93 \\
\hline $\begin{array}{l}\text { Negative } \\
\text { control }\end{array}$ & 0 & 184 & & 105 & & 89 & & 72 & \\
\hline $\begin{array}{l}\text { Positive } \\
\text { Control }\end{array}$ & 5 & 2096 & 11.39 & 758 & 7.21 & 563 & 6.325 & 360 & 5 \\
\hline
\end{tabular}

Table 6: Mutagenic potential of sitagliptin and aspartame in combination

\begin{tabular}{|c|c|c|c|c|c|c|c|c|c|}
\hline \multicolumn{10}{|c|}{ Sitagliptin + aspartame } \\
\hline \multirow[t]{3}{*}{ No. } & \multirow{3}{*}{$\begin{array}{c}\text { Conc. } \\
\text { ( } \mu \mathrm{g} / \text { plate) }\end{array}$} & \multicolumn{8}{|c|}{ Revertant colonies/plate } \\
\hline & & \multicolumn{4}{|c|}{ TA 100} & \multicolumn{4}{|c|}{ TA 98} \\
\hline & & $+S 9$ & M.I. & -59 & M.I. & +59 & M.I. & -59 & M.I. \\
\hline$\overline{1}$ & $190+150$ & 143 & 0.77 & 72 & 0.68 & 99 & 1.11 & 92 & 1.27 \\
\hline 2 & $380+300$ & 167 & 0.9 & 86 & 0.81 & 163 & 1.83 & 105 & 1.45 \\
\hline 3 & $760+600$ & 196 & 1.06 & 92 & 0.87 & 183 & 2.05 & 113 & 1.56 \\
\hline 4 & $1520+1200$ & 206 & 1.12 & 124 & 1.18 & 190 & 2.13 & 129 & 1.79 \\
\hline 5 & $3040+2400$ & 155 & 0.84 & 80 & 0.76 & 154 & 1.73 & 62 & 0.86 \\
\hline Negative control & 0 & 184 & & 105 & & 89 & & 72 & \\
\hline Positive Control & 5 & 2096 & 11.39 & 758 & 7.21 & 563 & 6.325 & 360 & 5 \\
\hline
\end{tabular}


Table 7: Mutagentic potential of sitagliptin and acesulfame- $\mathrm{K}$ in combination

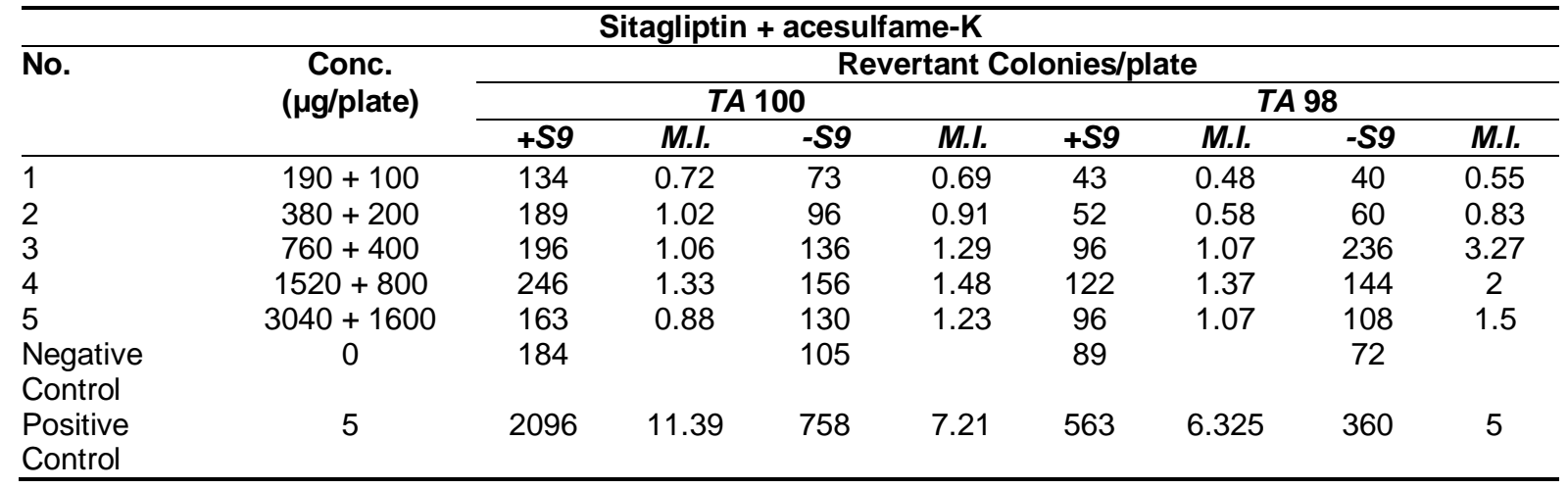

Combined doses of sitagliptin + acesulfame-K (Fig 3) when investigated for genotoxicity using comet assay, the damage indices of $3,7,17,22$ and 37 were calculated against the combined doses of $190+100 \mu \mathrm{g} / \mathrm{mL}, \quad 380+200 \mu \mathrm{g} / \mathrm{mL}$, $760+400 \mu \mathrm{g} / \mathrm{mL}, \quad 1520+800 \mu \mathrm{g} / \mathrm{mL}$ and $3040+1600 \mu \mathrm{g} / \mathrm{mL}$. When sitagliptin + acesulfame-k results compared with the genotoxic effect of sitagliptin alone, no significant difference in the result occurred. Sitagliptin + acesulfame-k when evaluated in combination (Table 7) for mutagenicity results exhibited mutagenic potential at the combined doses of $760+400 \mu \mathrm{g} /$ plate and $1520+800 \mu \mathrm{g} /$ plate against TA98 without metabolic activation system. The results of combined doses of sitagliptin and acesulfame-k when compared with sitagliptin alone the difference in the result was significant.

\section{DISCUSSION}

Sitagliptin was genotoxic at its higher concentrations. DNA damage was maximum at the concentration of $1520 \mu \mathrm{g} / \mathrm{mL}$ and 3040 $\mu \mathrm{g} / \mathrm{mL}$. The damage indices at these concentrations were 9 and 20 respectively. These findings were in accordance to a clinical review in which peripheral lymphocytes of the type 2 diabetic patients were used and results exhibited that the sitagliptin demonstrated genotoxic impacts [14].

The saccharin also showed genotoxic potential. These outcomes were in line with Ashby and Ishidate's review [15] who reported the clastogenic impacts of saccharin on the Chinese hamster lung (CHL) fibroblasts. They recommended that the genotoxic impact of the saccharin may be because of the salts particles. On the other hand the positive mutagenic results of saccharin might be due to the impurities of the saccharin which showed greater mutagenic effects on TA98 than TA100 strains of Salmonella typhimurium [16].
The comet results of Aspartame were similar to the positive dose dependent chromosome aberration test [17]. However the positive mutagenic results of aspartame endorse the statement that aspartame possesses mutagenic activity and is capable of causing more than one type of cancer [18]. Aspartame in gastrointestinal tract is broken into its metabolites, aspartic acid, methanol and phenylalanine. Methanol is further oxidized in to formaldehyde and formate. Formic acid is the reason for most of the harmful effects in human and animals [19].

Genotoxic and mutagenic positive results of acesulfame- $k$ indicates that acesulfame- $\mathrm{K}$ is capable of interacting with the genetic material of the cell only at high doses [20].

When the sitagliptin and the artificial sweeteners were evaluated in combination the results depicts enhance in both genotoxic and mutagenic potential.

\section{CONCLUSION}

Sitagliptin exhibits mutagenic potential at higher concentrations alone and in combination with artificial sweeteners. It also exhibits genotoxic behavior in a dose-dependant manner. Although sitagliptin, in combination with artificial sweetener, did not display a higher genotoxicity relative to compound alone, care still need to be taken by diabetic patients while being treated with the anti-diabetic drugs and concurrently using artificial sweeteners for a long period of time.

\section{DECLARATIONS}

\section{Acknowledgement}

The authors are grateful to Dr Imran Altaf Quality Operation Laboratory, University of Veterinary and Animal Sciences Lahore, Pakistan for 
providing all the facilities and guideline to complete this research work successfully.

\section{Conflict of Interest}

No conflict of interest associated with this work.

\section{Contribution of Authors}

The authors declare that this work was done by the authors named in this article and all liabilities pertaining to claims relating to the content of this article will be borne by them.

\section{Open Access}

This is an Open Access article that uses a funding model which does not charge readers or their institutions for access and distributed under the terms of the Creative Commons Attribution License (http://creativecommons.org/licenses/by/ 4.0) and the Budapest Open Access Initiative (http://www.budapestopenaccessinitiative.org/rea d), which permit unrestricted use, distribution, and reproduction in any medium, provided the original work is properly credited.

\section{REFERENCES}

1. Brazg R, Xu L, Dalla Man C, Cobelli C, Thomas K, Stein PP. Effect of adding sitagliptin, a dipeptidyl peptidase-4 inhibitor, to metformin on 24-h glycaemic control and $\beta$-cell function in patients with type 2 diabetes. Diabetes Obes. Metab. 2007; 9 (2): 186-193.

2. Matveyenko AV, Dry S, Cox HI, Moshtaghian A, Gurlo T, Galasso R, Butler AE, Butler PC. Beneficial endocrine but adverse exocrine effects of sitagliptin in the human islet amyloid polypeptide transgenic rat model of type 2 diabetes interactions with metformin. Diabetes 2009; 58 (7): 1604-1615.

3. Seewoodhary $J$ and Bain SC. Diabetes, diabetes therapies and cancer: what's the link? The $B J$ Diabetes Vasc Dis 2011; 11(5): 235-238

4. Forte $V$, Pandey A, Abdelmessih R, Forte G, WhaleyConnell A, Sowers JR, McFarlane SI. Obesity, diabetes, the cardiorenal syndrome, and risk for cancer. Cardiorenal med 2012; 2(2): 143-162.

5. Kant $R$. Sweet protein potential replacement for artificial low calorie sweeteners. Nutr J 2005; 4: 1-6.

6. Weihrauch MR and Diehl V. Artificial sweeteners-do they bear a carcinogenic risk? Ann Oncol 2004; 15(10): 1460-1465.

7. Garland EM, Shapiro R, Wehner JM, Johnson LS, Mattson BJ, Khachab M, Asamoto M, Cohen SM. Effects of dietary iron and folate supplementation on the physiological changes produced in weanling rats by sodium saccharin exposure. Food Chem Toxicol 1993; 31(10): 689-699.

8. Abhilash M, Sauganth Paul MV, Varghese MV, Nair RH. Long-term consumption of aspartame and brain antioxidant defense status. Drug Chem Toxicol 2011; 36(2): 135-140.

9. Zhang $G H$, Chen $M L$, Liu SS, Zhan $Y H$, Quan, $Y$, Qin $Y M$, Deng SP. Effects of mother's dietary exposure to acesulfame- $K$ in pregnancy or lactation on the adult offspring's sweet preference. Chem senses 2011; 36(9): 763-770.

10. National Institute of Health. USA. Public health service policy on human care and use of laboratory animals, 2002.

11. Tice RR, Agurell E, Anderson D, Burlinson B, Hartmann A, Kobayashi H Miyamae Y, Rojas E, Ryu JC, Sasaki YF. Single cell gel/comet assay: guidelines for in vitro and in vivo genetic toxicology testing. Environ $\mathrm{Mol}$ Mutagen 2000; 35(3): 206-221.

12. Valencia-Quintana R, Gómez-Arroyo S, Waliszewski SM, Sánchez-Alarcón J, Gómez-Olivares JL, FloresMárquez AR, Cortes-Eslava J, Villalobos-Pietrini $R$. Evaluation of the genotoxic potential of dimethyl sulfoxide (DMSO) in meristematic cells of the root of Vicia faba. Toxicol Environ Health Scien 2012; 4(3): 154-160.

13. Mortelmans K, Zeiger E. The Ames Salmonella microsome mutagenicity assay. Mutat Res 2000; 455: 29-60.

14. Gul OO, Cinkilic N, Gul CB, Cander S, Vatan O, Ersoy C. Yılmaz D, Tuncel E. Comparative genotoxic and cytotoxic effects of the oral antidiabetic drugs sitagliptin, rosiglitazone, and pioglitazone in patients with type-2 diabetes: a cross-sectional, observational pilot study. Mutat Res 2013; 18; 757(1): 31-35.

15. Ashby $\mathrm{J}$ and Ishidate $\mathrm{M}$. Clastogenicity in vitro of the $\mathrm{Na}$, $\mathrm{K}, \mathrm{Ca}$ and $\mathrm{Mg}$ salts of saccharin; and of magnesium chloride; consideration of significance. Mutat Res 1986; 163(1): 63-73.

16. Stoltz DR, Stavric B, Krewski $D$, Klassen $R$, Bendall $R$, Junkins $B$. Mutagenicity screening of foods $I$. Results with beverages. Environ mutagen 1982; 4(4): 477-492.

17. AlSuhaibani ES. In vivo cytogenetic studies on aspartame. Compa Funct Geno 2010; 4 pages

18. Soffritti M, Belpoggi F, Degli Esposti D, Lambertini L, Tibaldi E. Rigano A. First experimental demonstration of the multipotential carcinogenic effects of aspartame administered in the feed to Sprague-Dawley rats. Environ Health Perspect 2006; 114(3): 379-385.

19. Butchko HH, Stargel WW. Aspartame: scientific evaluation in the postmarketing period. Regul Toxicol Pharmacol 2001; 34(3): 221-233.

20. Mukherjee A, Chakrabarti J. In vivo cytogenetic studies on mice exposed to acesulfame-K: $A$ non-nutritive sweetener. Food Chem Toxicol 1997; 35(12): 11771179. 